\title{
PELATIHAN PENULISAN ARTIKEL ILMIAH BAGI GURU-GURU KIMIA DI KABUPATEN BULELENG
}

\author{
oleh, \\ I Wayan Redhana, I Made Kirna, I Nyoman Suardana, dan I Wayan Subagia \\ Fakultas Matematika dan IPA \\ Universitas Pendidikan Ganesha
}

\begin{abstract}
ABSTRAK
Tujuan kegiatan P2M ini adalah menghasilkan produk berupa artikel ilmiah yang siap diterbitkan dalam Jurnal Pendidikan Kimia Indonesia (JPKimIa) melalui pelatihan. Kegiatan pelatihan yang dilakukan meliputi berkoordinasi dengan MGMP Kimia Kabupaten Buleleng mengenai jadwal dan tempat pelaksanaan P2M, pelatihan pencarian informasi atau browsing internet, pembekalan penulisan artikel ilmiah, pelatihan menganalisis artikel jurnal yang telah dipublikasikan, dan pembuatan artikel ilmiah. Jumlah peserta kegiatan sebanyak 30 orang guru-guru kimia. Hasil kegiatan P2M adalah guru-guru kimia sangat antusias mengikuti pelatihan P2M.
\end{abstract}

Kata-kata kunci: pelatihan, artikel ilmiah, guru kimia

\begin{abstract}
The purpose of this activity is to produce a product $\mathrm{P} 2 \mathrm{M}$ be prepared scientific articles published in the Journal of Chemical Education Indonesia (JPKimIa) through training. Training activities undertaken include coordination with Chemistry MGMPs Buleleng on schedule and place of P2M, training information search or browse the internet, debriefing writing scientific articles, analyzing training journal articles have been published, and the manufacture of scientific articles. The number of participants in as many as 30 teachers of chemistry. Results P2M activities are chemistry teachers are very enthusiastic about the training P2M.
\end{abstract}

Key words: training, scientific articles, chemistry teacher

\section{Pendahuluan}

Jabatan fungsional guru adalah jabatan fungsional yang mempunyai ruang lingkup, tugas, tanggung jawab, dan wewenang untuk melakukan kegiatan mendidik, mengajar, membimbing, mengarahkan, melatih, menilai, dan mengevaluasi peserta didik pada pendidikan anak usia dini jalur pendidikan formal, pendidikan dasar, dan pendidikan menengah sesuai dengan peraturan perundang-undangan yang diduduki oleh Pegawai Negeri Sipil. Guru adalah pendidik profesional dengan tugas utama mendidik, mengajar, membimbing, mengarahkan, melatih, menilai, dan mengevaluasi peserta 
didik pada pendidikan anak usia dini jalur pendidikan formal, pendidikan dasar, dan pendidikan menengah. Oleh karena itu, peranan guru dalam memajukan pendidikan dan dalam menyiapkan sumber daya manusia yang berkualitas sangat penting dan strategi.

Mengingat pentingnya peranan guru dalam memajukan pendidikan nasional dan menyiapkan sumber daya manusia yang berkualitas, guru yang berkualitas di masa sekarang dan di masa yang akan datang mutlak diperlukan. Untuk itu, pemerintah melalui Menteri Negara Pendayaan Aparatur Negara mengeluarkan Permenegpan Nomor 16 Tahun 2009 tentang Jabatan Angka Fungsional Guru dan Angka Kreditnya. Unsur dan subunsur kegiatan guru yang dinilai angka kreditnya meliputi pendidikan, pembelajaran/ pembimbingan, pengembangan keprofesian berkelanjutan, dan penunjang. Pengembangan keprofesian berkelanjutan meliputi subunsur pengembangan diri, publikasi ilmiah, dan karya inovatif. Publikasi ilmiah dapat meliputi publikasi ilmiah atas hasil penelitian atau gagasan inovatif pada bidang pendidikan formal dan publikasi buku teks pelajaran. Pada Pasal 16 Ayat (2) dinyatakan bahwa "Untuk kenaikan jabatan/pangkat setingkat lebih tinggi dari guru pertama, pangkat penata muda, golongan ruang IIIa sampai dengan guru utama, pangkat pembina utama, golongan ruang IVe wajib melakukan kegiatan pengembangan keprofesian berkelanjutan yang meliputi subunsur pengembangan diri, publikasi ilmiah, dan/atau karya inovatif.” Peraturan ini mulai berlaku 1 Januari 2011. Ini mengisyaratkan kepada kita bahwa guru-guru harus melakukan pengembangan diri jika mengusulkan kenaikan jabatan/pangkat. Salah satu pengembangan diri yang dapat dilakukan oleh guru-guru adalah dengan membuat karya ilmiah yang dipublikasikan dalam jurnal ilmiah.

Untuk membantu guru-guru kimia alumni Jurusan Pendidikan Kimia dalam mempublikasikan hasil-hasil penelitian atau gagasan pemikiran kritisnya, Ikatan Alumni Jurusan Pendidikan Kimia (IKA-Kim) FMIPA Universitas Pendidikan Ganesha (Undiksha) membuat suatu wadah komunikasi ilmiah yang berupa jurnal ilmiah. Jurnal ini kemudian diberi nama Jurnal Pendidikan Kimia Indonesia (disingkat JPKimIa). Dalam perkembangannya, keberadaan jurnal ini tidak hanya untuk menampung hasilhasil penelitian dari guru-guru kimia alumni Jurusan Pendidikan Kimia Undiksha, tetapi juga untuk mempublikasikan karya dari seluruh peneliti, praktisi, pemerhati pendidikan, dan pengembang kurikulum, khususnya dalam bidang pendidikan kimia. Melalui media 
komunikasi berupa JPKimIa ini, para peneliti dan praktisi dalam bidang pendidikan kimia dapat menyebarluaskan hasil-hasil penelitian dan gagasannya kepada masyarakat ilmiah sehingga masyarakat ilmiah dapat mengimplementasikan hasil-hasil penelitian atau gagasan kritis tersebut untuk meningkatkan kualitas pendidikan di negara kita. Selain oleh guru-guru kimia, hasil-hasil penelitian yang dipublikasikan dalam JPKimIa ini juga dapat dimanfaatkan oleh semua pemangku kepentingan, termasuk dinas pendidikan dan perguruan tinggi dalam rangka meningkatkan kualitas pendidikan.

JPKimIa terbit dua kali setahun, yaitu periode April dan Oktober. Setiap terbitan memerlukan sekitar 10 artikel. Untuk memperoleh jumlah 10 artikel setiap terbitan atau nomor tentu bukan pekerjaan yang mudah. Memang ada kebijakan di Jurusan Pendidikan Kimia bahwa kekurangan artikel akan dipenuhi dari artikel skripsi mahasiswa S1. Selain itu, kekurangan artikel setiap terbitan akan di-back up oleh artikel dari dosen-dosen di Jurusan Pendidikan Kimia.

Kenyataannya, jumlah artikel yang diharapkan dari guru-guru kimia alumni Jurusan Pendidikan Kimia sangat kurang. Apa yang menjadi harapan ketika JPKimIa di bentuk yaitu mewadahi hasil-hasil penelitian atau gagasan dari guru-guru kimia, tidak dapat terpenuhi. Dari dua nomor yang sudah terbit, kebanyakan tulisan berasal dari dosendosen dan mahasiswa Jurusan Pendidikan Kimia yang telah menyelesaikan skripsi. Jurusan Pendidikan Kimia memang mewajibkan kepada mahasiswa agar membuat artikel hasil penelitian dari skripsinya. Artikel inilah yang sementara menjadi penopang pemenuhan artikel JPKimIa.

Direktorat Jenderal Pendidikan Tinggi (Ditjen Dikti) Kementerian Pendidikan dan Kebudayaan mengeluarkan Surat Edaran Nomor 152/E/T/2012 tentang Publikasi Karya Ilmiah. Isi surat edaran tersebut adalah sebagai berikut. Pertama, untuk lulus program sarjana, mahasiswa harus telah menghasilkan makalah yang terbit pada jurnal ilmiah. Kedua, untuk lulus program magister, mahasiswa harus telah menghasilkan makalah yang terbit pada jurnal ilmiah nasional, diutamakan yang terakreditasi Dikti. Ketiga, untuk lulus program doktor, mahasiswa harus telah menghasilkan makalah yang terbit pada jurnal internasional. Ketentuan ini merupakan pemecahan atas masalah paceklik publikasi ilmiah. Pemerintah berasumsi bahwa pengejaran kuantitas publikasi ilmiah dapat dijadikan indikasi peningkatan kualitas karya ilmiah. 
Berkaitan dengan surat edaran tersebut, mahasiswa Jurusan Pendidikan Kimia telah memiliki wadah untuk menerbitkan artikel skripsinya dalam JPKimIa (Jurnal Pendidikan Kimia Indonesia). Oleh karena itu, kehadiran JPKimIa ini juga merupakan solusi bagi mahasiswa Jurusan Pendidikan Kimia yang mungkin sulit menerbitkan artikelnya hasil penelitian skripsinya. Ini berarti, JPKimIa tidak akan kekurangan artikel untuk setiap terbitan, paling tidak disuplai oleh artikel dari hasil penelitian skripsi mahasiswa di Jurusan Pendidikan Kimia.

Namun, jurnal yang baik adalah jurnal yang mempublikasikan artikel yang berasal dari luar. Dengan kata lain, jurnal tidak hanya memuat artikel dari dalam atau kalangan sendri (Jurusan Pendidikan Kimia Undiksha), tetapi juga memuat artikel dari luar. Salah satu syarat jurnal agar bisa diakreditasi oleh Dikti adalah artikel yang dimuat paling tidak $60 \%$ berasal dari luar. Ini tentu pekerjaan yang tidak mudah.

Untuk dapat memenuhi kebutuhan artikel yang berasal dari luar, pihak pengelola perlu melakukan sosialisasi JPKimIa kepada penulis luar. Untuk hal ini, sosialisasi telah dilakukan kepada guru-guru kimia yang ada di propinsi Bali, Jawa Timur, dan Nusa Tenggara Barat, dan Nusa Tenggara Timur ketika rapat IKA-Kim. Pengelola juga telah melakukan sosialisasi JPKimIa ke universitas di luar Undiksha, seperti Universitas Pendidikan Indonesia, Universitas Negeri Semarang, Universitas Negeri Surabaya, dan Universitas Sriwijaya dengan cara mengirimkan contoh terbitan JPKimIa kepada salah satu dosen di universitas tersebut dan mengimbau dosen yang bersangkutan menulai artikel dan agar mengarahkan mahasiswanya menulis artikel di JPKimIa. Pengelola juga telah membuat web JPKimIa di web Undiksha. Namun, karena JPKimIa belum terakreditasi, para penulis masih enggan memasukkan artilkel atau tulisannya.

Penulis luar yang paling layak disasar adalah guru-guru kimia alumni Jurusan Pendidikan Kimia Undiksha yang ada di propinsi Bali. Namun, secara umum kemampuan guru-guru kimia menulis artikel ilmiah masih sangat rendah. Untuk itu, melalui kegiatan Pengabdian pada Masyarakat (P2M) ini, pengelola memberikan pelatihan tentang penulisan artikel ilmiah bagi guru-guru kimia. Mengingat jangkauan dan jumlah guru-guru kimia yang sangat banyak, kegiatan pelatihan ini dilakukan secara bertahap, yaitu setiap tahunnya dilaksanakan pelatihan di satu kabupaten/kota. Pada tahun 2011, kegiatan pelatihan penulisan artikel bagi guru-guru kimia ini telah 
dilakukan di kabupaten Gianyar. Dari kegiatan di kabupaten Gianyar ini telah dihasilkan dua artikel yang telah terbit di JPKimia. Untuk tahun 2012 ini, kegiatan P2M tentang pelatihan penulisan artikel ilmiah bagi guru-guru kimia dilaksanakan di kabupaten Karangasem. Sementara itu, kegiatan pelatihan penulisan artikel ilmiah bagi guru-guru kimia pada tahun 2013 ini akan dilaksanakan di kabupaten Buleleng.

Kemampuan guru-guru kimia yang ada di kabupaten Buleleng dalam menulis karya ilmiah secara umum masih sangat rendah, walaupun diakui bahwa beberapa guru-guru kimia telah memiliki kemampuan menulis karya ilmiah yang cukup memadai. Dua orang guru di kabupaten Buleleng yang cukup aktif menulis adalah I Gede Putra Adnyana, S.Pd. M.Pd. (Guru SMAN 2 Busungbiu) dan Drs. I Wayan Soma (Guru SMAN 4 Singaraja). Mereka cukup intensif mengirim tulisan ke redaksi JPKimIa. Drs. I Wayan Soma juga merupakan guru teladan tingkat kabupaten Buleleng pada tahun 2009. Namun, keberhasilan beberapa orang guru kimia ini tidak diikuti oleh guru kimia lainnya. Beberapa permasalahan yang dapat diidentifikasi berkaitan dengan rendahnya kemampuan guru-guru kimia di kabupaten Buleleng menulis artikel ilmiah dapat diuraikan sebagai berikut.

Pertama, guru-guru kimia kurang memiliki sumber-sumber informasi, seperti buku dan jurnal. Hal ini dikemukakan oleh beberapa orang guru kimia bahwa mereka tidak memiliki buku atau jurnal sehingga mereka tidak dapat mendukung tulisannya dengan teori-teori yang ada. Demikian juga perpustakaan yang ada di daerah di daerah tidak menyediakan jurnal ilmiah yang memadai untuk mendukung tulisan ilmiah yang dibuat oleh guru-guru. Walaupun mereka tidak memiliki sumber informasi yang memadai, mereka sesungguhnya dapat mengakses atau melakukan browsing informasi di internet. Asalkan mereka dapat menuliskan kata-kata kunci dengan tepat, mereka akan memperoleh informasi dimaksud dengan cepat. Beberapa sekolah terutama mantan Rintisan Sekolah Bertaraf Internasional (RSBI) telah memiliki jaringan internet di sekolahnya. Namun, mereka belum bisa memanfaatkan jaringan internet ini secara maksimal karena mereka kebingungan atau tidak mengetahui cara mengangkses informasi dengan cepat dan tepat. Akibatnya, mereka seperti ayam bertelur di padi, namun mati kelaparan. Artinya, fasilitas internet sudah tersedia, namun mereka belum bisa memanfaatkan fasilitas internet tersebut secara optimal. 
Kedua, guru-guru kimia umumnya tidak memiliki hasil penelitian atau gagasan untuk ditulis. Hal ini sangat berkaitan dengan masalah pertama, yaitu kurangnya tersedia sumber informasi berupa buku dan jurnal tentang pendidikan. Walaupun guruguru kimia tidak memiliki hasil penelitian untuk ditulis, mereka dapat menulis gagasan inovatifnya. Gagasan ini dapat diperoleh dari membaca hasil-hasil penelitian atau gagasan pemikiran orang lain. Masalah utama adalah mereka malas membaca materi yang berkaitan dengan pendidikan kimia.

Ketiga, kemampuan guru-guru kimia dalam menulis atau menuangkan ide dalam tulisan secara umum masih sangat rendah. Guru-guru kimia umumnya tidak terbiasa menulis. Pekerjaan menulis, dalam hal ini artikel ilmiah, memerlukan latihan dan kebiasaan. Keterampilan menulis ini tidaklah dibawa sejak lahir, melainkan diperoleh melalui proses pembelajaran dan latihan. Orang memiliki keterampilan menulis artikel ilmiah karena mereka berlatih menulis artikel. Hasil tulisannya pasti kurang baik pada awal mereka belajar menulis. Seiring dengan waktu dan latihan yang keras dan sungguh-sungguh, mereka akan dapat melahirkan artikel berkualitas.

Terakhir, guru-guru kimia tidak memahami aturan tata tulis ilmiah dalam jurnal ilmiah. Mereka membuat judul sangat panjang, bahkan mereka mengkopi judul penelitian menjadi judul artikel. Masalah lainnya adalah pembuatan abstrak. Mereka membuat abstrak lebih dari 200 kata, bahkan satu halaman dengan spasi tunggal. Demikian juga dengan jumlah kata-kata kunci. Mereka membuat lebih dari lima katakata kunci. Pada bagian pendahuluan, mereka menguraikan terlalu panjang lebar teori dan mereka sering mengambil kalimat atau paragraf dari buku atau tulisan orang lain tanpa menyebutkan sumbernya. Di samping itu, tulisan yang dibuat oleh guru-guru kimia sering tidak berkaitan antara paragraf yang satu dengan paragraf yang lain. Sementara itu pada metode penelitian, mereka menulis desain penelitian tidak jelas. Untuk bagian hasil dan pembahasan mereka tidak menyajikan hasil secara ringkas. Rata-rata tidak disertai dengan standar deviasi. Demikian juga sering terjadi penyajian ganda, data yang sama disajikan dalam berbagai bentuk. Artinya, data sudah disajikan dalam bentuk tabel, juga disajikan dalam bentuk grafik. Dalam hal pembahasan, guruguru tidak membahas temuan secara mendalam, melainkan menarasikan temuan atau 
hasil secara panjang lebar. Demikian juga guru-guru kurang membandingkan temuannya dengan temuan lain yang dihasilkan oleh peneliti lain.

Kondisi di atas akan menjadikan guru-guru kimia sebagai konsumen ide, bukan sebagai produsen ide. Guru-guru kimia hendaknya dapat menghasilkan ide-ide atau gagasan inovatif yang dapat dibagi (di-sharing) kepada sesama profesi. Jika setiap orang guru kimia dapat menghasilkan ide-ide inovatif dan membaginya kepada guruguru kimia lain, maka ide-ide tersebut akan dapat dimiliki oleh guru-guru lain. Dengan kata lain, proses berbagi (memberi dan menerima) akan dapat berlangsung dengan baik. Inilah yang sesungguhnya disebut sebagai masyarakat ilmiah dan masyarakat belajar (learning community).

Luaran yang diharapkan dari kegiatan P2M ini adalah artikel ilmiah yang siap dipublikasikan dalam JPKimIa. Dengan demikian, rumusan permasalahan yang akan dicari jawabannya setelah guru-guru kimia mengikuti kegiatan P2M ini adalah sebagai berikut. (1) Berapa jumlah produk artikel ilmiah yang dapat dihasilkan oleh guru-guru kimia di kabupaten Buleleng yang siap dipublikasikan dalam JPKimIa?, (2) Bagaimana kualitas artikel ilmiah yang dihasilkan oleh guru-guru kimia di kabupaten Buleleng? Manfaat dari kegiatan P2M dapat diuraikan sebagai berikut. (1) Guru-guru kimia khususnya di kabupaten Buleleng diharapkan memiliki pengetahuan dan keterampilan menulis artikel ilmiah. Pengetahuan dan keterampilan ini juga dapat dimanfaatkan oleh guru-guru untuk membimbing karya ilmiah siswa di sekolahnya masing-masing. (2) Dihasilkannya artikel ilmiah dalam bidang pendidikan kimia yang siap diterbitkan dalam JPKimIa sehingga keberlangsungan terbit dari JPKimIa ini dapat dipertahankan. Di samping itu, dengan tersedianya artikel dalam jumlah yang memadai, pengelola JPKimIa dapat menyeleksi artikel yang ada sehingga artikel yang dimuat atau diterbitkan memiliki kualitas yang baik.

\section{Metode Pelaksanaan Pengabdian}

Kabupaten Buleleng terletak di bagian utara pulau Bali yang berjarak $80 \mathrm{~km}$ dari kota Denpasar. Lokasi kegiatan adalah di SMA Negeri 1 Singaraja yang berjarak sekitar $2 \mathrm{~km}$ dari Universitas Pendidikan Ganesha. Lokasi kegiatan dapat ditempuh dengan kendaraan pribadi atau kendaraan umum. Sasaran dari kegiatan P2M ini adalah guru- 
guru kimia yang tergabung dalam MGMP kabupaten Buleleng yang berjumlah sekitar 30 orang. Kemampuan guru-guru kimia dalam menulis artikel ilmiah masih sangat kurang. Masih sangat sedikit (empat orang) guru-guru kimia yang berasal dari Kabupaten Buleleng yang memasukkan artikelnya ke JPkimIa. Padahal, beberapa guru kimia di kabupaten Buleleng memiliki kemampuan melakukan penelitian dan mampu menulis artikel.

Pemecahan masalah di atas didekati dengan menggunakan kerangka berpikir, seperti ditunjukkan di bawah. Masalah yang ada di lapangan diidentifikasi, kemudian dirumuskan alternatif pemecahan masalahnya. Kemudian, dari alternatif pemecahan masalah yang berhasil diidentifikasi, dipilih alternatif yang paling mungkin dan tepat sasaran untuk mengatasi masalah yang ada. Setelah memilih alternatif yang paling mungkin dan tepat sasaran, selanjutnya dirumuskan metode kegiatan/pelaksanaan pemecahan masalah.

Metode pelaksanaan kegiatan berupa pelatihan. Waktu Pelaksanaan kegiatan P2M dari tanggal 2 Agustus 2013 sampai dengan 2 Oktober 2013. Kegiatan pelatihan penulisan artikel ilmiah dilakukan dengan langkah-langkah sebagai berikut. Berkoordinasi dengan MGMP Kimia kabupaten Buleleng. Penulis berkoordinasi dengan pengurus MGMP Kimia kabupaten Buleleng berkaitan dengan kegiatan pelatihan, terutama mengenai tempat dan jadwal pelaksanaan. Kegiatan pelatihan ini akan dilaksanakan sekitar bulan Juli sampai Agustus 2013. Pengurus MGMP diharapkan dapat membantu penulis menyiapkan prasarana dan sarana penunjang pelaksanaan kegiatan pelatihan. Pengurus MGMP juga menyurati anggota MGMP untuk menjadi peserta dalam kegiatan pelatihan. Jumlah guru-guru kimia yang terlibat dalam kegiatan P2M ini sekitar 30 orang.

Pelatihan pencarian informasi atau browsing internet. Kegiatan ini diawali dengan pemberian informasi atau pembekalan kepada seluruh peserta tentang cara-cara dan triktrik cepat pencarian informasi yang berkaitan dengan artikel jurnal, buku, makalah, materi bidang studi, animasi dan video pembelajaran, dan sebagainya di internet. Setelah pembekalan, seluruh peserta berlatih mengakses informasi di internet.

Pembekalan penulisan artikel ilmiah. Pembekalan penulisan artikel ilmiah meliputi tentang pedoman penulisan pada JPKimIa. Untuk artikel hasil penelitian, cakupan 
materinya meliputi kriteria judul, identitas penulis, abstrak, pendahuluan, metode penelitian, hasil dan pembahasan, penutup, dan daftar rujukan. Sementara itu, untuk artikel kajian putaka atau hasil gagasan, cakupan materinya meliputi kriteria judul, identitas penulis, abstrak, pendahuluan, pembahasan, penutup, dan daftar rujukan. Penulisan daftar rujukan menggunakan sistem American Phsychological Association (APA) meliputi antara lain: (1) penulisan buku cetakan dengan satu penulis, (2) buku cetakan dengan dua penulis, (3) buku cetakan dengan editor sebagai penulis, (4) buku review cetakan dengan dua orang penulis, (5) brosur cetakan tanpa tahun dan tanpa penulis, (6) bab dalam buku cetakan yang ada editornya, (7) bab dalam buku cetakan yang ada edisi dan editornya, (8) disertasi/tesis/skripsi yang tidak dipublikasikan yang ada dalam database, (9) laporan pemerintah/koorporasi yang dipublikasikan secara online, (10) artikel jurnal dengan dua orang penulis yang dipublikasikan secara online dan mengandung doi (digital object installer), (11) artikel jurnal cetakan dengan satu orang penulis, (12) artikel jurnal yang dipublikasikan secara online oleh dua orang penulis, tanpa doi, (13) artikel jurnal oleh tiga sampai enam orang penulis yang dipublikasikan secara online dengan doi, (14) artikel jurnal cetakan oleh tujuh atau lebih orang penulis, (15) karya individu di internet, (16) artikel jurnal di internet, (17) artikel majalah cetakan, (18) artikel majalah online yang ditemukan dalam database tanpa doi, (19) artikel jurnal dalam CD-ROM, (20) artikel koran online tanpa doi, (21) artikel koran cetakan dengan penulis, (22) artikel koran cetakan tanpa penulis, (23) makalah atau poster yang dipresentasikan dalam pertemuan, (24) dokumen resmi pemerintah yang diterbitkan oleh suatu penerbit tanpa penulis dan tanpa lembaga, (25) karya terjemahan, skripsi, tesis, dan disertasi, (26) makalah yang disajikan dalam seminar, penataran atau lokakarya, (27) bahan diskusi di internet, (28) email pribadi, (29) website tanpa penulis dan tanpa tahun, (30) makalah dipresentasikan dalam pertemuan, dan (31) abstrak diakses online tanpa doi.

Materi berikutnya adalah cara pengutipan. Jenis kutipan terdiri atas: (1) satu pekerjaan oleh satu orang penulis, (2) satu pekerjaan oleh dua orang penulis, (3) satu pekerjaan oleh tiga orang penulis, (4) satu pekerjaan oleh empat orang penulis, (5) satu pekerjaan oleh lima orang penulis, (6) satu pekerjaan oleh enam orang penulis atau lebih, (7) kelompok (ada singkatan sebagai penulis), dan (8) kelompok (tanpa singkatan 
sebagai penulis). Selain itu, juga dipaparkan materi tentang penggunaan "dan" versus "\&," cara pengutipan, dan penggunaan bahasa dan tanda baca.

Pelatihan menganalisis artikel jurnal yang telah dipublikasikan. Setelah peserta diberi pembekalan tentang materi penulisan artikel ilmiah. Peserta selanjutnya berlatih menilai artikel jurnal yang telah dipublikasikan. Peserta diminta menerapkan pengetahuan yang dimiliki untuk menilai artikel jurnal.

Pembuatan artikel ilmiah. Kegiatan selanjutnya adalah peserta menulis artikel ilmiah berdasarkan hasil-hasil penelitian atau gagasan ilmiahnya. Selama penulisan ini peserta dibimbing oleh pelatih (pelaksana P2M). Kegiatan penulisan ini dilanjutkan di rumah masing-masing peserta dan mereka diminta sudah membawa artikel akhir pada bulan berikutnya guna diberikan masukan-masukan untuk menyempurnakan artikel tersebut.

Rancangan Evaluasi. Keberhasilan dari kegiatan pelatihan penulisan artikel ilmiah bagi guru-guru kimia di kabupaten Buleleng dilihat dari kuantitas dan kualitas produk artikel ilmiah yang dihasilkan dari kegiatan pelatihan tersebut. Tabel berikut menyajikan aspek yang dievaluasi dan kriteria indikator pencapaian tujuan.

Tabel 1. Rancangan evaluasi

\begin{tabular}{|l|l|}
\hline \multicolumn{1}{|c|}{ Aspek yang dievaluasi } & \multicolumn{1}{c|}{ Indikator pencapaian tujuan } \\
\hline $\begin{array}{l}\text { Artikel ilmiah yang dihasilkan } \\
\text { oleh guru-guru kimia selama } \\
\text { kegiatan P2M }\end{array}$ & $\begin{array}{l}\text { Jumlah artikel yang siap dipublikasikan dalam } \\
\text { JPKimIa paling tidak 20\% dari jumlah peserta } \\
\text { pelatihan }\end{array}$ \\
\cline { 2 - 2 } & $\begin{array}{l}\text { Rara-rata kualitas artikel yang dihasilkan dari } \\
\text { kegiatan pelatihan minimum tergolong baik, dengan } \\
\text { skor minimal 70. }\end{array}$ \\
\hline
\end{tabular}

Jumlah peserta pelatihan sebanyak 30 orang guru kimia. Dengan asumsi setiap guru kimia membuat satu artikel ilmiah, dengan demikian minimal akan ada 6 artikel yang siap dipublikasikan dalam JPKimIa. Sementara itu, untuk penilaian artikel menggunakan rubrik. Rubrik ini dibuat dengan mengadaptasi rubrik yang dikembangkan oleh tim pengelola Jurnal Ilmu Pendidikan (Universitas Negeri Malang).

\section{Hasil dan Pembahasan}

Jumlah guru-guru kimia di kabupaten Buleleng Bali yang berpartisipasi dalam kegiatan ini sebanyak 30 orang. Peserta sangat antusias mengikuti kegiatan P2M ini. 
Hal ini disebabkan oleh mereka belum pernah memperoleh materi atau pelatihan tentang penulisan artikel ilmiah sebelumnya. Mereka aktif bertanya tentang kaedah penulisan artikel ilmiah. Beberapa guru yang pernah mengikuti pendidikan S2, sekarang ini mereka menyadari kekurangannya dalam menulis tulis karya ilmiah. Misalnya, mereka sering membuat judul artikel ilmiah sama dengan judul penelitian (thesis) sehingga judul tulisan sangat panjang, lebih dari 20 kata. Demikian juga ketika mereka menulis abstrak. Mereka membuat abstrak satu halaman dengan jumlah kata lebih dari 200 kata dan dibuat dalam tiga paragraf. Untuk kata kunci, mereka membuatnya lebih dari lima kata kunci dan banyak kata yang tidak penting dijadikan kata kunci, seperti kata pembelajaran. Apalagi pendahuluan, mereka sering membuat pendahuluan dengan mengutip terlalu banyak dari buku-buku atau tulisan orang lain sehingga pendahuluan yang dibuat kurang menggambarkan masalah yang dipecahkan. Permasalahan lainnya adalah ketika mereka membuat pembahasan, mereka sering mengulangi pernyataan hasil yang dibuat dalam bentuk deskripsi. Tidak ada ide penulis yang ditampilkan dalam pembahasan dan juga hasil-hasil yang diperoleh tidak dikomparasikan dengan temuantemuan oleh penulis lain. Terakhir, permasalahan yang ditemukan adalah tidak konsistennya penulisan daftar rujukan. Dengan pelatihan ini mereka merasa lebih percaya diri menulis artikel ilmiah untuk diterbitkan dalam JPKimIa. Mereka berusaha memperbaiki kekurangan yang dimiliki.

Bagi guru-guru kimia yang memang senang menulis, mereka merasa memperoleh manfaat yang sangat besar dengan dilatihnya mereka tentang penulisan artikel ilmiah. Mereka menjadi lebih bersemangat menulis dan sekarang mengetahui trik mencari sumber-sumber informasi di internet. Mereka merasa tidak ada kendala dalam mencari informasi di internet. Di lain pihak juga ditemukan bahwa bagi guru-guru yang tidak pernah menulis, baik berupa artikel ilmiah, laporan penelitian, dan sebagainya, mereka mengalami kesulitan mengikuti materi pelatihan ini. Beberapa dari mereka menyatakan bahwa materi yang diberikan cukup tinggi dan sulit. Hal ini beralasan karena mereka tidak pernah membaca buku-buku atau jurnal ilmiah, bahkan mereka tidak pernah melakukan penelitian.

Pelatihan ini selain dapat memberikan wawasan dan keterampilan kepada mereka dalam menulis artikel ilmiah, mereka juga merasa lebih percaya diri dalam 
membimbing siswa dalam pembuatan karya tulis ilmiah. Biasanya setiap tahun diadakan lomba karya tulis ilmiah bagi siswa SMA, baik di tingkat kabupaten, provinsi, nasional, maupun internasional. Siswa-siswa SMA dari kabupaten Buleleng sudah ada yang lolos dalam ajang lomba karya tulis ilmiah di tingkat nasional, dan bahkan internasional. Para guru berharap agar mereka dapat meningkatkan prestasi siswanya dalam lomba karya tulis. Selain itu, juga ada lomba karya tulis untuk guru. Beberapa dari guru kimia memiliki semangat yang tinggi untuk mengikuti lomba karya tulis di tingkat kabupaten, provinsi, dan bahkan nasional.

Hasil evaluasi terhadap kuantitas dan kualitas artikel dari kegiatan P2M ini adalah sebagai berikut. Tidak ada guru yang mengumpulkan artikel ilmiah yang akan diterbitkan dalam JPKimia. Salah satu alasan guru-guru kimia adalah mereka belum sempat menulis artikel karena mereka sibuk mengajar. Alasan yang lainnya adalah mereka baru memulai penelitian sehingga belum ada bahan hasil penelitian yang akan ditulis menjadi artikel. Alasan berikutnya adalah mereka baru saja naik pangkat/jabatan sehingga mereka belum membutuhkan kredit point dari artikel saat ini. Walaupun demikian, mereka merasa memiliki wawasan tentang penulisan karya ilmiah, baik dalam penulisan proposal penelitian, laporan penelitian, maupun artikel ilmiah. Mereka akan bersusaha melakukan penelitian untuk dapat ditulis menjadi artikel di kemudian hari, apalagi dengan diberlakukannya Permenegpan Nomor 16 Tahun 2009 tentang Jabatan Angka Fungsional Guru dan Angka Kreditnya bahwa guru wajib membuat pengembangan profesi untuk dapat diangkat pada jabatan yang lebih tinggi, tidak terkecuali golongannya.

Secara jujur diakui bahwa kegiatan P2M ini belum mencapai target yang ditetapkan. Seperti telah diuraikan di atas, kegiatan ini tidak sepenuhnya gagal karena guru-guru kimi telah memiliki wawasan, pengetahuan dan keterampilan dalam penulisan karya ilmiah. Tidak saja menulis artikel, guru-guru kimia juga memiliki wawasan dalam membuat proposal penelitian dan laporan penelitian. Peningkatan pemahaman guru-guru kimia tentang kaedah penulisan ilmiah merupakan suatu keberhasilan juga, walaupun bukan menjadi target utama. Demikian juga, mereka merasa lebih percaya diri dalam membimbing siswa dalam lomba karya tulis ilmiah. 


\section{Penutup}

Kegiatan P2M tentang penulisan artikel ilmiah telah dilaksanakan dengan jumlah peserta sebanyak 30 orang guru-guru kimia di kabupaten Buleleng. Tidak ada guru-guru kimia yang mengumpulkan artikel sampai kegiatan P2M ini berakhir. Beberapa alasan yang dikemukakan oleh guru-guru kimia adalah mereka sibuk mengajar, mereka belum memiliki penelitian untuk ditulis menjadi artikel, dan mereka baru saja naik pangkat atau jabatan sehingga mereka tidak membutuhkan kredit point saat ini. Walaupun demikian, guru-guru kimia sangat antusias mengikuti kegiatan pelatihan dan mereka merasa memperoleh pengetahuan dan keterampilan tetang penulisan karya ilmiah. Mereka juga merasa lebih siap membimbing siswanya dalam lomba penulisan karya ilmiah.

\section{DAFTAR PUSTAKA}

Anonim (2010). Cara efektif mencari informasi di Google. Tersedia pada: http:http://internet-marketing-gratis.blogspot.com/2010/06/cara-efektif-mencariinformasi-di.html. Diakses pada tanggal 20 februari 2011.

Anonim. (2010). EYD terbaru (Permendiknas Nomor 46 Tahun 2009). Yogyakarta: Pustaka Timur.

Chaer, A. (2011). Ragam bahasa ilmiah. Jakarta: Rineka Cipta.

Direktorat Jenderal Pendidikan Tinggi (Ditjen Dikti) Kementerian Pendidikan dan Kebudayaan, Surat Edaran Nomor 152/E/T/2012 tentang Publikasi Karya Ilmiah.

Jurnal Pendidikan Kimia Indonesia (2001). Alumni Jurusan Pendidikan Kimia Undiksha.

Keduax (2011). Teknik Mencari Informasi di Google. Tersedia pada: http: http://keduax.wordpress.com/2011/02/20/teknik-mencari-informasi-di-google.

Diakses pada tanggal 20 februari 2011.

Lima Adi Sekawan. (2009). EYD Pus. Jakarta: Limas.

Peraturan Menteri Negara Pendayaan Aparatur Negara Nomor 16 Tahun 2009 tentang Jabatan Angka Fungsional Guru dan Angka Kreditnya.

Santoso, U. (2010). Kiat-kiat pemulisan artikel ilmiah dalam jurnal ilmiah internasional. tersedia pada: http://uripsantoso.wordpress.com/2008/06/04. Diakses tanggal 20 februari 2012. 
Sugihastuti. (2000). Bahasa laporan penelitian. Yogyakarta: Pustaka Belajar.

Surat Edaran Direktorat Jenderal Pendidikan Tinggi Kementerian Pendidikan dan Kebudayaan No. 152/E/T/2012 Tanggal 27 Januari 2012 tentang Publikasi Karya Ilmiah.

Tanjung, H. B. N. \& Ardial, H. (2010). Pedoman penulisan karya ilmiah dan mempersiapkan diri menjadi penulis artikel ilmiah. Jakarta: Prenada Media Group. 